\title{
Human aortic smooth muscle cells are insulin resistant at the receptor level but sensitive to IGF1 and IGF2
}

\author{
S I Chisalita, G S Johansson, E Liefvendahl, K Bäck and H J Arnqvist \\ Division of Cell Biology, Faculty of Health Sciences, Diabetes Research Centre and Department of Clinical and Experimental Medicine, Linköping University, 10 th Floor, S-581 85 \\ Linköping, Sweden \\ (Correspondence should be addressed to H J Arnqvist; Email: hans.arnqvist@liu.se)
}

\begin{abstract}
Whether insulin, at physiological concentrations, has direct effects on vascular smooth muscle cells (VSMCs) remains controversial. Our aim was to characterize the mechanism for insulin resistance in VSMCs. For comparison, the effects of IGF1 and IGF2 were also studied. Cultured human aortic smooth muscle cells (HASMC) were used. Receptor mRNA was analyzed by quantitative reverse transcription PCR and receptor protein by ELISA and western blot. Biological effects were studied by thymidine incorporation and glucose accumulation. In HASMC, both mRNA and protein expression of IGF1 receptors (IGF1R) were fivefold higher compared to insulin receptor (IR). IR isoform A mRNA was 13-fold more expressed than IR isoform B. IR and IGF1R co-precipitated, indicating the presence of hybrid IR/IGF1R. Phosphorylation of the IGF1R $\beta$-subunit was obtained by IGF1 $10^{-9}-10^{-8} \mathrm{~mol} / \mathrm{l}$ and IGF2 $10^{-8} \mathrm{~mol} / \mathrm{I}$. IR $\beta$-subunit was phosphorylated by IGF1 $10^{-8} \mathrm{~mol} / \mathrm{l}$ but not by insulin. IGF1 stimulated IR substrate-1 and AKT at $10^{-8} \mathrm{~mol} / \mathrm{l}$ and extracellular signal-regulated kinases 1 and 2 at $10^{-9}-10^{-8} \mathrm{~mol} / \mathrm{l}$ respectively. IGF1 and 2 at a concentration of $10^{-8}-10^{-7} \mathrm{~mol} / \mathrm{l}$ significantly stimulated ${ }^{3} \mathrm{H}$-thymidine incorporation, whereas insulin did not. ${ }^{14} \mathrm{C}$-Glucose accumulation was stimulated by IGF1 or IGF2 $10^{-8}-10^{-7} \mathrm{~mol} / \mathrm{l}$, and also by insulin $10^{-7} \mathrm{~mol} / \mathrm{l}$. Our results suggest that IGF1R and hybrid IR/IGF1R are activated by physiological concentrations of IGF1 and 2 in HASMC and this propagates downstream signaling and biological effects, while insulin has no effect on its receptor or downstream signaling probably due to a preponderance of IGF1R and incorporation of IR into hybrid IR/IGF1R.
\end{abstract}

Journal of Molecular Endocrinology (2009) 43, 231-239

\section{Introduction}

Insulin resistance, diabetes, and circulating insulin-like growth factor 1 (IGF1), have all been implicated in the pathogenesis of cardiovascular disease, but the mechanisms behind these associations are still not clear (De Meyts 1994, Conti et al. 2001, 2002, Juul et al. 2002, Lakka et al. 2002, Nathan et al. 2005). In the development of atherosclerosis vascular smooth muscle cells (VSMCs) proliferate, migrate, and produce extracellular matrix (Doran et al. 2008). Whether insulin, at physiological concentrations, has direct effects on VSMCs remains controversial. In vitro, the effects of insulin on muscular arteries or cultured VSMCs are small and only occur at high supraphysiological concentrations (Arnqvist 1974, Arnqvist et al. 1979, King et al. 1983, 1985). Insulin is closely related to IGF1 and 2 (Rinderknecht \& Humbel 1978 $a, b$ ). High concentrations of insulin can elicit effects on VSMCs by cross reacting with IGF1 receptors (Banskota et al. 1989, Avena et al. 1999). Insulin receptors (IRs) and IGF1Rs are homologs having $84 \%$ homology in the $\beta$-subunit tyrosine kinase domains (Ullrich et al. 1986). In tissues co-expressing IGF1R and IR, hybrid IGF1R/IR are formed (Moxham et al. 1989, Soos \& Siddle 1989,
Bailyes et al. 1997, Federici et al. 1997, Sakai \& Clemmons 2003). They consist of an IR $\alpha \beta$-monomer and an IGF1R $\alpha \beta$-monomer and have binding characteristics similar to the IGF1R (Bailyes et al. 1997, Federici et al. 1997, Pandini et al. 2002). The human IR exists in two isoforms, IRA and IRB, of which IRA has a high affinity for IGF2 (Mosthaf et al. 1990, Yamaguchi et al. 1991, Frasca et al. 1999, Denley et al. 2004). To initiate the biological effects of insulin, IGF1 and IGF2, the first step is binding and activation of membranebound receptors by phosphorylation, followed by recruitment and phosphorylation of docking proteins including insulin receptor substrate-1 (IRS1), extracellular signal-regulated kinases 1 and 2 (ERK 1/2), and AKT involved in the regulation of cell metabolism, proliferation, and survival (Dupont \& LeRoith 2001, Saltiel \& Kahn 2001).

We wanted to study whether insulin resistance of human VSMCs is due to low availability of IRs or impaired downstream signaling. Due to interactions of insulin, IGF1 and IGF2 at the receptor level and common downstream signaling (Kim \& Accili 2002), studying their action at physiological concentrations is of great importance for revealing mechanisms of insulin resistance.

DOI: 10.1677/JME-09-002 Online version via http://www.endocrinology-journals.org 
Here we investigated effects of insulin, IGF1 and IGF2 on receptors, downstream signaling, and biological effects in human aortic smooth muscle cells (HASMCs).

\section{Materials and methods}

Primers and probes for quantitative real-time reverse transcription PCR (RT-PCR) were purchased from Scandinavian Gene Synthesis AB (SGS, Köping, Sweden). Primary antibodies used for immunoprecipitation (IP) and immunoblotting studies included monoclonal mouse anti-tyrosine PY20 antibody and polyclonal rabbit antibodies for IR $\beta$-subunit (C-19), IGF1R $\beta$-subunit (C-20), IRS-1 (C-20), phospho-AKT 1/2/3 (Thr208), all purchased from Santa Cruz Biotechnology, Inc (Santa Cruz, CA, USA). Polyclonal rabbit antibodies for total AKT, phospho-ERK 1/2 (Thr202/Tyr204) and total ERK 1/2 were bought from Cell Signaling (Boston, MA, USA). Goat anti-rabbit-HRP (Zymed, San Francisco, CA, USA), sheep anti-mouse-HRP (Amersham Pharmacia Biotechnology), and streptavidine-HRP (Amersham Pharmacia Biotechnology) were used as secondary antibodies. Enhanced chemiluminescence (ECL) detection system was obtained from Amersham Pharmacia Biotechnology. D- $\left[\mathrm{U}^{14}-\mathrm{C}\right]$-glucose $(317 \mathrm{mCi} \mathrm{nmol} / \mathrm{l})$ and $\left[6-{ }^{3} \mathrm{H}\right]$-thymidine $(20 \mathrm{Ci} \mathrm{nmol} / \mathrm{l})$ were obtained from Amersham Pharmacia Biotechnology.

\section{Culture of cells}

HASMC from three different batches were obtained from Gibco Invitrogen. They tested negative for von Willebrand Factor VIII and positive for $\alpha$-smooth muscle actin. The cells were cultured in accordance with the manufacturer's instructions in smooth muscle cell growth medium, which consisted of medium 231 (smooth muscle cell basal medium), together with smooth muscle growth supplement and amphotericin $1.6 \mathrm{mg} / \mathrm{ml}$, penicillin $100 \mathrm{IU} / \mathrm{ml}$, and streptomycin $20 \mathrm{IU} / \mathrm{ml}$. HASMC were cultured at $37^{\circ} \mathrm{C}$ in $95 \mathrm{v} / \mathrm{v} \%$ air with $5 \mathrm{v} / \mathrm{v} \% \mathrm{CO}_{2}$. Cell culture material was bought from Corning (Schiphol-Rijk, The Netherlands). All experiments were performed in triplicate or more, on near confluent cell cultures in passage 4-8.

\section{Quantitative real-time RT-PCR}

RNA was extracted using the RNeasy Mini Kit (Qiagen $\mathrm{GmbH})$. From $1 \mu \mathrm{g}$ RNA first strand cDNA was transcribed using a commercial kit (Invitrogen $\mathrm{AB}$, Life Technologies). The expression of $I R$ and IGF1R was estimated by real-time quantitative RT-PCR (QRTPCR) assay using the ABI PRISM 7500 Sequence Detection System (PE Applied Biosystems, Stockholm, Sweden). The oligonucleotides were purchased from SGS, see used primers and probes listed in Table 1. The real-time RT-PCR reaction was run in a 7500 Prism Sequence Detector System (PE Applied Biosystems). Twelve microlitres TaqMan Universal PCR Master Mix (PE Applied Biosystems), $3 \mu \mathrm{l}$ cDNA of reverse transcribed RNA, $300 \mathrm{nmol} / 1$ primers, $25 \mathrm{nmol} / 1$ probe for $I R$, and $50 \mathrm{nmol} / 1$ probe for IGF1R respectively were added in a final volume of $25 \mu \mathrm{l}$. After $2 \mathrm{~min}$ at $50{ }^{\circ} \mathrm{C}$ and $10 \mathrm{~min}$ at $95^{\circ} \mathrm{C}$, the reaction ran for 40 cycles consisting of a denaturation or melting step at $95^{\circ} \mathrm{C}$ for $15 \mathrm{~s}$, followed by an annealing/extension step at $60^{\circ} \mathrm{C}$ for $1 \mathrm{~min}$. The detection of the PCR products was allowed through the combination of $5^{\prime}-3^{\prime}$ nuclease activity of AmpliTaq Gold DNA Polymerase ROX by the release of a fluorescent reporter FAM for $I R$ and $I G F I R$ and VIC for GAPDH probes oligonucleotides during the RT-PCR reaction. The fluorescence was measured at each cycle. The relative amount of transcripts,

Table 1 Sequences for the primers and probes used in the quantitative real-time reverse transcription (RT)-PCR

Primer/probe

\section{Gene \\ IGF1R}

IR

IRA

IRB

GAPDH

\author{
Forward primer \\ Reverse primer \\ Probe \\ Forward primer \\ Reverse primer \\ Probe \\ Forward primer \\ Reverse primer \\ Probe \\ Forward primer \\ Reverse primer \\ Probe \\ Forward primer \\ Reverse primer \\ Probe
}

Sequence 
measured during the exponential phase of reaction, was determined by the comparative $C_{\mathrm{t}}$ methods (Bulletin 2, PE Applied Biosystems).

\section{IGF1R ELISA}

The amount of IGF1R protein was measured using ELISA. Cell lysate was prepared from near confluent cell cultures. The cells were washed twice with cold PBS and then collected in cold PBS. The cell-PBS suspension was centrifuged at $700 \mathrm{~g} 4{ }^{\circ} \mathrm{C}$ for $5 \mathrm{~min}$. The resulting pellet was lysed in lysis buffer ( $\mathrm{pH} 7.5$ ) containing $20 \mathrm{mmol} / 1$ Trizma base, $150 \mathrm{mmol} / 1 \mathrm{NaCl}, 5 \mathrm{mmol} / 1 \mathrm{EDTA}, 0 \cdot 5 \%$ sodium deoxycholate, and $0.5 \%$ Triton X-100 with an addition of $1 \mathrm{mmol} / 1$ phenylmethylsulfonyl fluoride (PMSF), $1.5 \mu \mathrm{g} / \mathrm{ml}$ leupeptin, $1 \mathrm{mmol} / 1 \mathrm{Na}_{3} \mathrm{VO}_{4}$, and $1.5 \mu \mathrm{g} / \mathrm{ml}$ aprotinin prior to use. The cells were lysed on ice for $30 \mathrm{~min}$ and then centrifuged at $4{ }^{\circ} \mathrm{C}, 12000 \mathrm{~g}$ for $10 \mathrm{~min}$. Supernatant was stored at $-70^{\circ} \mathrm{C}$ until further use. The plate used in the assay was 96 -well Maxisorp plates (NUNC, Roskilde, Denmark) which was coated over night at $4{ }^{\circ} \mathrm{C}$ with monoclonal anti-human IGF1R antibodies (MAB 391; R\&D Systems, Abingdon, UK) diluted as $2 \mathrm{mg} / \mathrm{l}$ in coating buffer $\left(15 \mathrm{mmol} / 1 \mathrm{Na}_{2} \mathrm{CO}_{3}\right.$, $35 \mathrm{mmol} / 1 \mathrm{NaHCO}_{3}, \mathrm{pH} \mathrm{9 \cdot 6).} \mathrm{On} \mathrm{day} 2$ the wells were washed three times with $0.05 \mathrm{v} / \mathrm{v} \%$ Tween 20 in PBS (PBS-T) to remove unbound fractions of antibody before blocking with $5 \mathrm{w} / \mathrm{v} \% \mathrm{BSA}$ and $0.02 \mathrm{w} / \mathrm{v} \% \mathrm{NaN}_{3}$ in PBS for $1 \mathrm{~h}$ at RT, followed by another wash with PBS-T. Recombinant human IGF1R (R\&D Systems) was used as standard. Samples and standards, all diluted in $0 \cdot 1$ $\mathrm{w} / \mathrm{v} \%$ human serum albumin (HSA) in PBS, were incubated on a shaker for $2 \mathrm{~h}$ at RT. After washing away the unbound fraction with PBS-T, the secondary antibody was added and incubated on a shaker at RT for $2 \mathrm{~h}$. The biotinylated anti-human IGF1R antibody (BAF 391; R\&D Systems) was diluted as $0.5 \mathrm{mg} / 1$ in $0 \cdot 1$ w/v \% HSA in PBS. After washing HRP conjugated streptavidine diluted $1: 500$ in $0 \cdot 1 \mathrm{v} / \mathrm{v} \%$ PBS-T was added to the plate, and incubated on a shaker for $20 \mathrm{~min}$ at RT. The plate was then washed in PBS and substrate for the HRP was incubated with the substrate for $30 \mathrm{~min}(0.4 \mathrm{mg} / 1$ tetramethylbenzidine dihydrochloride dissolved in phosphate-citrate buffer ( $35 \mathrm{mmol} / \mathrm{l}$ citric acid, $67 \mathrm{mmol} / 1 \mathrm{Na}_{2} \mathrm{HPO}_{4}$; $\mathrm{pH} 5 \cdot 0$ ) with $0 \cdot 006 \mathrm{v} / \mathrm{v} \% \mathrm{H}_{2} \mathrm{O}_{2}$ ). The reaction was then stopped by the addition of $1 \mathrm{~mol} / 1 \mathrm{H}_{2} \mathrm{SO}_{4}$ and the optical densities were measured at $450 \mathrm{~nm}$.

\section{IR ELISA}

The amount of IR protein was measured using an IR Immunoassay Kit (BioSource Europe S.A., Nivelles, Belgium) according to the manufacturer's instructions. Cell lysate was prepared as described above.

\section{Phosphorylation and cell lysis}

HASMC were cultured in $75 \mathrm{~cm}^{2}$ flasks until near confluent and serum starved for $24 \mathrm{~h}$ before experiment. The cultures were incubated with concentrations of $10^{-10}-10^{-8} \mathrm{~mol} / 1$ for IGF1, IGF2 or insulin in warm F-12-BSA medium for $10 \mathrm{~min}$ at $37^{\circ} \mathrm{C}$. After incubation, the cells were lysed for $30 \mathrm{~min}$ on ice with a lysis buffer containing (20 mmol/l Tris (pH 7.5), $150 \mathrm{mmol} / \mathrm{l}$ $\mathrm{NaCl}, 5 \mathrm{mmol} / 1 \mathrm{EDTA}, 0.5 \mathrm{w} / \mathrm{v} \%$ sodium deoxychelate, $0.5 \mathrm{w} / \mathrm{v} \%$ Triton X-100, $1 \mathrm{mmol} / 1 \mathrm{Na}_{3} \mathrm{VO}_{4}$, $1.5 \mu \mathrm{g} / \mathrm{ml}$ Aprotinin, $1.5 \mu \mathrm{g} / \mathrm{ml}$ Leupeptin, and $1 \mathrm{mmol} / \mathrm{l} \mathrm{PMSF})$. Cell lysates were centrifuged for $15 \mathrm{~min}$ at $12000 \mathrm{~g}$ at $4^{\circ} \mathrm{C}$. The resulting supernatant, the whole cell lysate, was transferred into new tubes and stored at $-70{ }^{\circ} \mathrm{C}$. Total protein content was measured by the bicinchoninic acid method (Pierce, Rockford, IL, USA) in order to adjust the amount of protein used for subsequent analysis.

\section{SDS-PAGE and western blot analysis}

To study IGF1R and IR $\beta$-subunits and also IRS1, cell lysates containing $0 \cdot 5-1 \mathrm{mg}$ total protein were immunoprecipitated with $0 \cdot 4-0 \cdot 6 \mu \mathrm{g}$ antibody per $\mathrm{mg}$ total protein content. Antibodies used for IP were polyclonal anti-IGF1R $\beta$-subunit antibody C-20, polyclonal anti-IR $\beta$-subunit antibody C-19 or IRS1 antibody C-20 respectively. All of the above were from Santa Cruz Biotechnology, Inc. Protein-A Sepharose (PharmaciaUpjohn) was added and samples were shaken gently overnight at $4{ }^{\circ} \mathrm{C}$. The immunoprecipitates were washed and centrifuged three times with ice-cold lysis buffer and diluted in $50 \mu \mathrm{l} 2 \times$ Laemmli sample buffer $(0.0125 \mathrm{~mol} / \mathrm{l}$ Trizma base, $2 \mathrm{w} / \mathrm{v} \%$ SDS, $20 \mathrm{w} / \mathrm{v} \%$ glycerol, $0.002 \mathrm{w} / \mathrm{v} \%$ bromophenol, $2 \mathrm{w} / \mathrm{v} \%$ $\beta$-mercaptoethanol, $\mathrm{pH} 6 \cdot 8$ ). Whole cell lysate samples were diluted in Laemmli sample buffer to a resulting total protein amount of $\sim 20 \mu \mathrm{g}$ per well.

Immunoprecipitated samples or whole cell lysate samples were boiled for $3 \mathrm{~min}$. After centrifugation, proteins in the supernatant were separated on a $7.5 \mathrm{w} / \mathrm{v}$ $\%$ SDS-PAGE gel. The separated proteins were electrotransferred onto a polyvinyl difluoride membrane and blocked in blocking buffer. The membrane was then immunoblotted over night at $4{ }^{\circ} \mathrm{C}$ with phospho-specific primary antibodies and visualized using secondary HRPlinked antibodies (Amersham, Life Science AB), followed by ECL detection. Autoradiographs were obtained by exposure to a Hyperfilm ECL (Amersham, Life Science $\mathrm{AB}$ ) and subsequently scanned with a LAS1000 camera (Image-Gauge, Fujifilm, Tokyo, Japan). Densitometric evaluation was performed using Multi Gauge Version 3.0 (FujiFilm), where data was registered as \% phosphorylated/total protein of maximum phosphorylated/total protein on each membrane. 


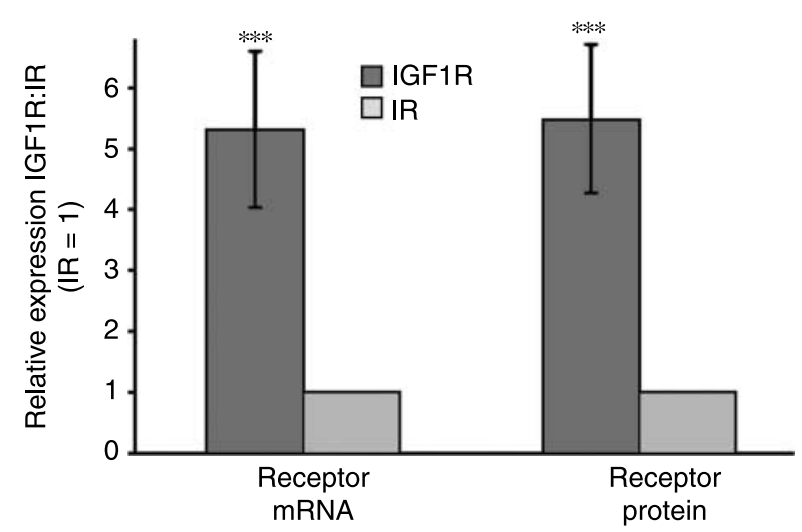

Figure 1 Expression of IR and IGF1R mRNA and proteins in HASMC. The relative amount of IGFIR to IR mRNA expression was measured by real-time RT-PCR, where $I R$ was set to 1 . The IGF1R and IR protein levels were analyzed by ELISA and are expressed as amount receptor protein relative to amount of total protein, IR was set to 1 . The IGF1R to IR mRNA ratio $(5 \cdot 3 \pm 1 \cdot 3)$ and the IGF1R to IR protein ratio $(5 \cdot 5 \pm 1 \cdot 2)$ was found to be almost identical. ${ }^{* * *}$ Denotes $P<0.001$ (mean \pm s.E.M., $n=4$ ).

The membranes were stripped by incubation in stripping buffer $(62.5 \mathrm{mmol} / \mathrm{l}$ Trizma $\mathrm{HCl}, 2 \mathrm{w} / \mathrm{v} \%$ SDS, $100 \mathrm{mmol} / 1 \quad \beta$-mercaptoethanol) at $55^{\circ} \mathrm{C}$ for $30 \mathrm{~min}$ and then reblotted with antibodies detecting the total amount of respective proteins.

\section{$\left[{ }^{3} \mathrm{H}\right]$-thymidine incorporation into DNA}

DNA-synthesis was quantified by measuring ${ }^{3} \mathrm{H}$-thymidine incorporation into DNA in HASMC. The cells were grown in 6-well plates until near confluency, serum starved for $24 \mathrm{~h}$ before experiment, and then for another $24 \mathrm{~h}$ with and without insulin, IGF1 or IGF2 at concentrations of $10^{-10}-10^{-7} \mathrm{~mol} / \mathrm{l}$, followed by incubation with $1 \mu \mathrm{Ci} / \mathrm{ml}^{3} \mathrm{H}$-thymidine (Amersham Pharmacia Biotechnology) for $3 \mathrm{~h}$. DNA was precipitated with cold $5 \mathrm{w} / \mathrm{v} \%$ trichloroacetic acid and then solubilized in $0.5 \mathrm{ml} 0.1 \mathrm{~mol} / 1 \mathrm{KOH}$. Part of the solution $0.4 \mathrm{ml}$ was added to $4 \mathrm{ml}$ scintillation solution, and the radioactivity was measured in a liquid scintillation counter (Rackbeta 1217, LKB Wallac, Turku, Finland). The data were expressed as the percentage increased in ${ }^{3} \mathrm{H}$-thymidine incorporation above basal.

\section{$\mathrm{D}-\left[\mathrm{U}^{14}-\mathrm{C}\right]$-glucose accumulation}

Near confluent HASMC grown in 6-well plates were starved in serum free media for $24 \mathrm{~h}$ before experiments. The cells were then incubated at $37^{\circ} \mathrm{C}$ for $2 \mathrm{~h}$ with the addition of $1 \mu \mathrm{Ci} / \mathrm{ml} \mathrm{D}-\left[\mathrm{U}^{14}-\mathrm{C}\right]$ glucose (Amersham Pharmacia Biotechnology) and in absence or presence of insulin, IGF1 or IGF2 at concentrations of $10^{-10}-10^{-7} \mathrm{~mol} / \mathrm{l}$. Thereafter, cells were rinsed three times with $\mathrm{PBS}$, lysed with $0.5 \mathrm{ml}$ $0.1 \mathrm{w} / \mathrm{v} \%$ SDS, and $0.4 \mathrm{ml}$ of the solubilized cells was added to $4 \mathrm{ml}$ scintillation solution, and the radioactivity was measured. The data were expressed as percent above basal.

\section{Statistical analysis}

Values are given as mean \pm s.E.M. Statistical comparisons were made with SPSS program (SPSS Inc. Headquarters, Chicago, IL, USA) by one-way ANOVA. As post-hoc test we used Dunnett's t-test (two-sided). A $P$ value $<0 \cdot 05$ was considered statistically significant.

\section{Results}

\section{Expression of IR and IGF1R}

Gene expression of $I R$ and $I G F 1 R$ was demonstrated in HASMC by quantitative real-time RT-PCR in cells starved for $24 \mathrm{~h}$ before experiments. IGFIR mRNA was approximately five times more abundant than $I R$ mRNA $(P<0.001$; Fig. 1$)$. IR and IGF1R were also measured as receptor proteins using ELISA and are expressed as receptor protein per mg of total protein. The amount of IGF1R protein was fivefold higher than IR protein, $8 \cdot 4 \pm 1 \cdot 2$ and $1 \cdot 5 \pm 0 \cdot 1 \mathrm{ng} / \mathrm{mg}$ total protein $(P<0.001)$ respectively (Fig. 1$)$. IR isoform A mRNA was 13-fold more abundant than IR isoform B $(P<0 \cdot 001$; Fig. 2).

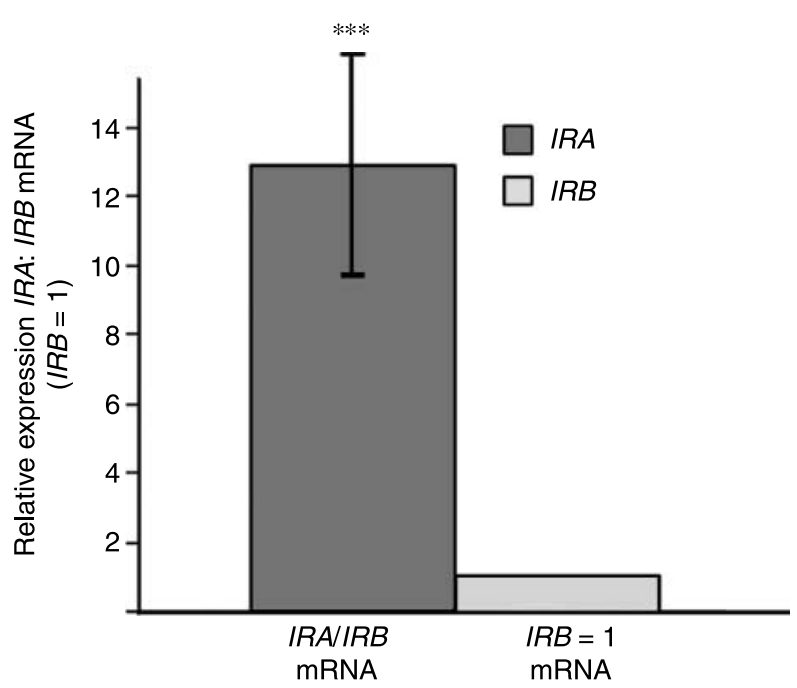

Figure 2 Expression of IR isoforms $A$ and $B$ in HASMC. The relative amount of $I R A$ to IRB was analyzed by real-time RT-PCR. IR isoform A was 13-fold (12.9 $\pm 3 \cdot 2)$ more abundant than IR isoform $\mathrm{B}(P<0.001)$, IRB was set to $1 .{ }^{* \star *}$ Denotes $P<0.001$ (mean \pm S.E.M., $n=4$ ). 


\section{Receptor $\beta$-subunit detection and activation}

After IP of receptors with anti-IR $\beta$-subunit (Fig. 3A and B) or anti-IGF1R $\beta$-subunit (Fig. 3C and D) specific antibodies and blotting the membrane with the same antibody, we found bands at a position slightly lower than the $97 \mathrm{kDa}$ molecular weight marker. The band detected with the IR-specific antibody (Fig. 3A and D) had a position slightly lower than the band detected by the IGF1R antibody (Fig. 3B and C). When the membrane with receptors immunoprecipitated and blotted with polyclonal, anti-IR was reblotted with IGF1R antibody a slightly higher band corresponding to the IGF1R $\beta$-subunit was found (Fig. 3B). The opposite result was found when the membrane immunoprecipitated and blotted with polyclonal antiIGF1R was reblotted with IR antibody (Fig. 3D). The co-precipitation of the IR and IGF1R $\beta$-subunits after IP against either of the two receptors $\beta$-subunits indicates the presence of insulin/IGF1 hybrid receptors.

To study receptor phosphorylation the cells were exposed to either insulin, IGF1 or IGF2 at concentrations of $10^{-10}-10^{-8} \mathrm{~mol} / 1$ for $10 \mathrm{~min}$. Insulin did not activate its cognate receptor or the IGF1 receptor (Fig. 4A and B). IGF1 was found to activate its own receptor at $10^{-9}-10^{-8} \mathrm{~mol} / \mathrm{l}$ and even the IR at $10^{-8} \mathrm{~mol} / \mathrm{l}$. IGF2 at $10^{-8} \mathrm{~mol} / \mathrm{l}$ activated the IGF1R and tended to activate the IR.

\section{Intracellular signaling}

Insulin $10^{-10}-10^{-8} \mathrm{~mol} / \mathrm{l}$ did not activate IRS1, AKT or ERK $1 / 2$ (Figs 5 and 6 ). IGF $110^{-8} \mathrm{~mol} / 1$ significantly phosphorylated IRS1 and AKT and at $10^{-9}-10^{-8} \mathrm{~mol} / 1$ phosphorylated ERK 1/2. IGF2 $10^{-8} \mathrm{~mol} / 1$ tended to activate IRS-1. ERK $1 / 2$ was not affected by $10^{-10}$ $10^{-8} \mathrm{~mol} / 1 \mathrm{IGF} 2$.
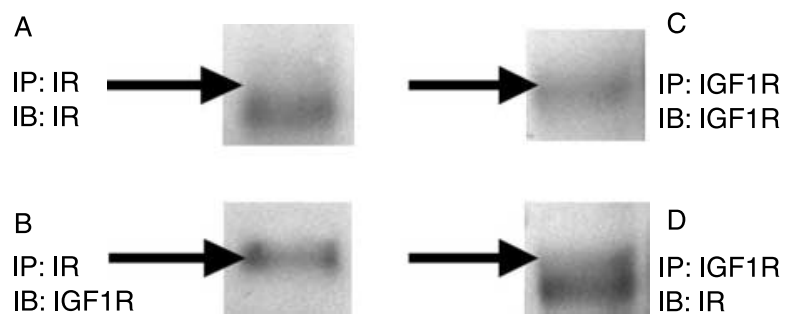

B: IGF1R

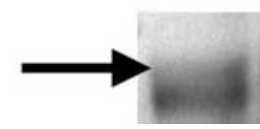

D IP: IGF1R IB: IR

Figure 3 Detection of IR and IGF1R $\beta$-subunits in HASMC. IR and IGF1R $\beta$-subunit protein and evidence for the presence of hybrid IR/IGF1R were demonstrated by immunoprecipitation and western blot. Insulin receptor (IR) $\beta$-subunit $(95 \mathrm{kDa})$ and IGF1R (IGF1R) $\beta$-subunit ( $97 \mathrm{kDa})$ were detected by western blot on the same membrane implying co-precipitation. Figures show blots after immunoprecipitation (IP) against either IR (left column, A and B), or IGF1R (right column, C and D) and immunoblot against the IR $\beta$-subunit (A and D) and the IGF1R $\beta$-subunit $(B$ and $C)$. Similar results were obtained in four independent experiments.

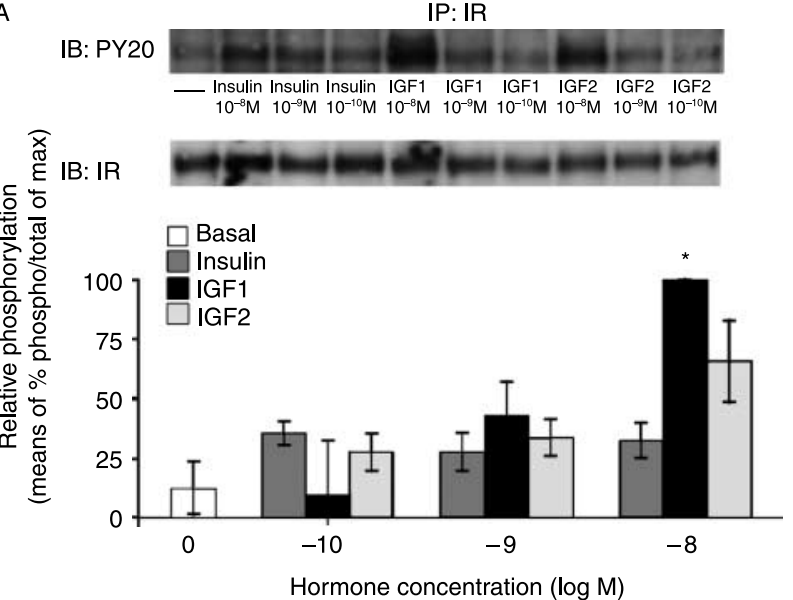

B

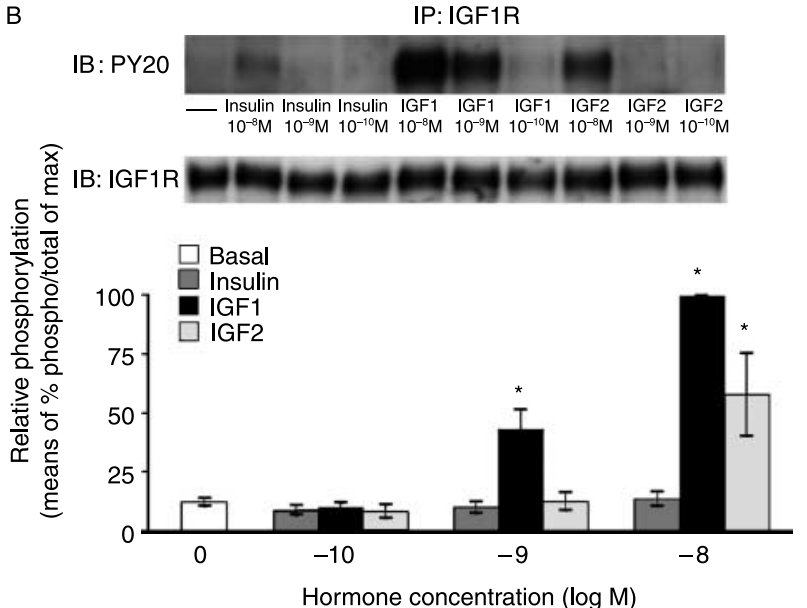

Figure 4 (A) Activation of IR $\beta$-subunit in HASMC. Effect of insulin (dark gray bars), IGF1 (black bars), and IGF2 (gray bars) on tyrosine phosphorylation of IR $\beta$-subunit were analyzed by immunoprecipitation of IR by an anti-IR $\beta$-subunit antibody and immunoblotting with an anti-phosphotyrosine antibody (PY20) after exposure of near confluent HASMC to insulin, IGF1, and IGF2 at the concentrations of $10^{-10}-10^{-8} \mathrm{~mol} / \mathrm{l}$ for $10 \mathrm{~min}$. Data are means from four independent experiments. Data were quantified by densitometry and are expressed as phosphorylated/total protein, fractional of maximal response. ${ }^{\star} P<0.05$.

(B) Activation of IGF1R $\beta$-subunit in HASMC. Effects of insulin (dark gray bars), IGF1 (black bars), and IGF2 (gray bars) on tyrosine phosphorylation of IGF1R $\beta$-subunit were analyzed by immunoprecipitation of IGF1R by an anti IGF1R $\beta$-subunit antibody and immunoblotting with an anti-phosphotyrosine antibody (PY20) after exposure of near confluent HASMC to insulin, IGF1, and IGF2 at the concentrations of $10^{-10}$ $10^{-8} \mathrm{~mol} / \mathrm{l}$ for $10 \mathrm{~min}$. Data are means from four independent experiments. Data were quantified by densitometry and are expressed as phosphorylated/total protein, fractional of maximal response. ${ }^{*} P<0.05$.

\section{Biological effects of IGF2, IGF1, and insulin}

The incorporation of $\left[{ }^{3} \mathrm{H}\right]$-thymidine into DNA was stimulated by $10^{-8}-10^{-7} \mathrm{~mol} / \mathrm{l}$ of IGF1 $(P=0.02$ and $P=0 \cdot 006)$ and IGF2 $(P=0 \cdot 001$ and $P \leq 0 \cdot 001)$, whereas 
A

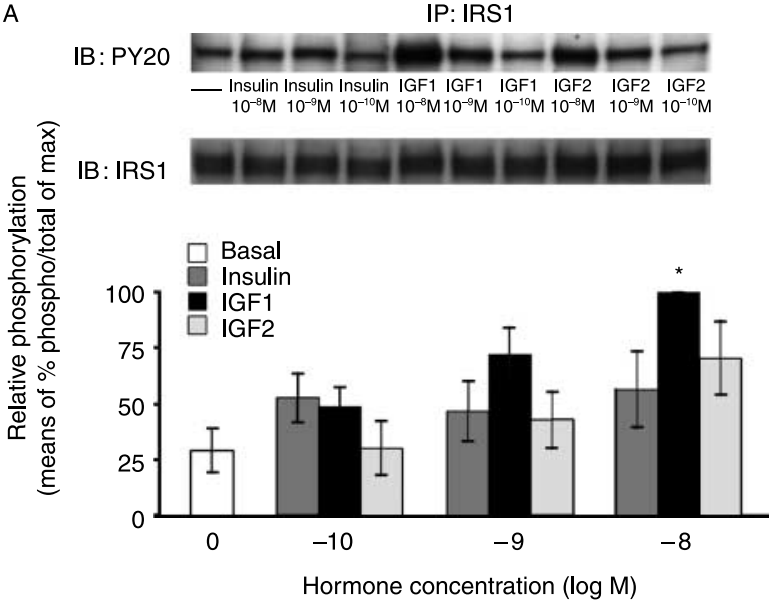

B

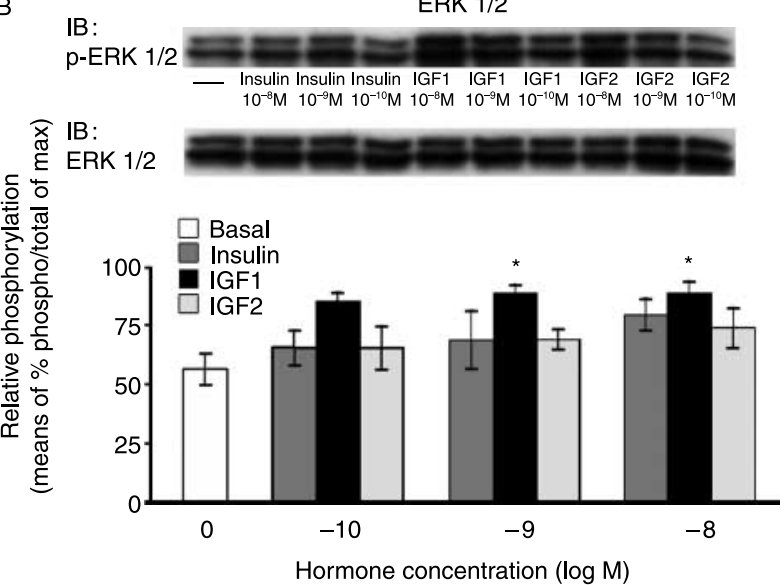

Figure 5 (A) Activation of insulin receptor substrate-1 (IRS1). HASMC were exposed for $10 \mathrm{~min}$ to insulin (dark gray bars), IGF1 (black bars), and IGF2 (gray bars) at concentrations of $10^{-10}-10^{-8} \mathrm{~mol} / \mathrm{l}$. Tyrosine phosphorylation of IRS1 was analyzed by immunoprecipitation of IRS1 with an IRS1 antibody and immunoblotting with an anti-phosphotyrosine antibody (PY20). Data are means \pm s.E.M., $n=4$. Data were quantified by densitometry and are expressed as means of percent phosphorylated/total protein, fractional of maximal response. ${ }^{\star} P<0.05$. (B) Activation of ERK 1/2.HASMC were exposed for 10 min to insulin (dark gray bars), IGF1 (black bars), and IGF2 (gray bars) at concentrations of $10^{-10}-10^{-8} \mathrm{~mol} / \mathrm{l}$. ERK $1 / 2$ phosphorylation was analyzed using a specific antibody detecting phospho-ERK $1 / 2$ phosphorylated at Thr 202 and Tyr 204. Data are means \pm S.E.M., $n=8$. Data were quantified by densitometry and are expressed as means of percent phosphorylated/total protein, fractional of maximal response. ${ }^{\star} P<0.05$.

insulin had no significant effect (Fig. 7A). Glucose accumulation was significantly stimulated by concentrations of $10^{-8}-10^{-7} \mathrm{~mol} / \mathrm{l}$ IGF $1 \quad(P=0.03$ and $P=0 \cdot 001)$ and IGF2 $(P<0 \cdot 001, P<0 \cdot 001)$, and also by insulin at the highest concentration of $10^{-7} \mathrm{~mol} / \mathrm{l}$ $(P=0 \cdot 001$; Fig. 7B).

\section{Discussion}

The effects of insulin, IGF1, and IGF2 on HASMCs were studied at the receptor level and further downstream. Insulin has a high affinity for its own receptor (Ward et al. 2007) and physiological effects of insulin are obtained at concentrations of $\leq 10^{-9} \mathrm{~mol} / \mathrm{l}$ in insulin sensitive tissues. In HASMC we could not demonstrate any activation of the IR by insulin; instead it was activated by IGF1 and also tended to be activated by IGF2. This observation can be explained by sequestration of IRs into hybrid IR/ IGF1R (Arnqvist 2008). In cells expressing both IGF1R and IR, hybrid IR/IGF1Rs are stoichiometrically formed depending on the relative abundance of IGF1R to IR (Pandini et al. 1999). Since IGF1R was several fold more expressed than IR in HASMC, most of the IRs will be incorporated into hybrid IR/IGF1Rs which have a low affinity for insulin, but bind IGF1 and IGF2 with the same affinity as IGF1 receptors (Soos et al. 1993, Siddle et al. 2001). According to the current model of insulin and IGF-binding to their own receptors, insulin needs to bind to both IR $\alpha$-subunits in the IR dimer to obtain high affinity binding, whereas for high affinity binding of IGF1 only one IGF1R $\alpha$-subunit is needed (Ward et al. 2007, De Meyts 2008). In the hybrid IR/ IGF1R the activated IGF1R $\beta$-subunit can transphosphorylate the IR $\beta$-subunit (Frattali \& Pessin 1993) as shown in this study.

IGF1Rs were expressed and activated at physiological IGF1 concentrations in HASMC, as previously shown in human coronary artery smooth muscle cells (Chisalita \& Arnqvist 2005). When membranes are developed with the anti-phosphotyrosine antibody PY20 it will detect

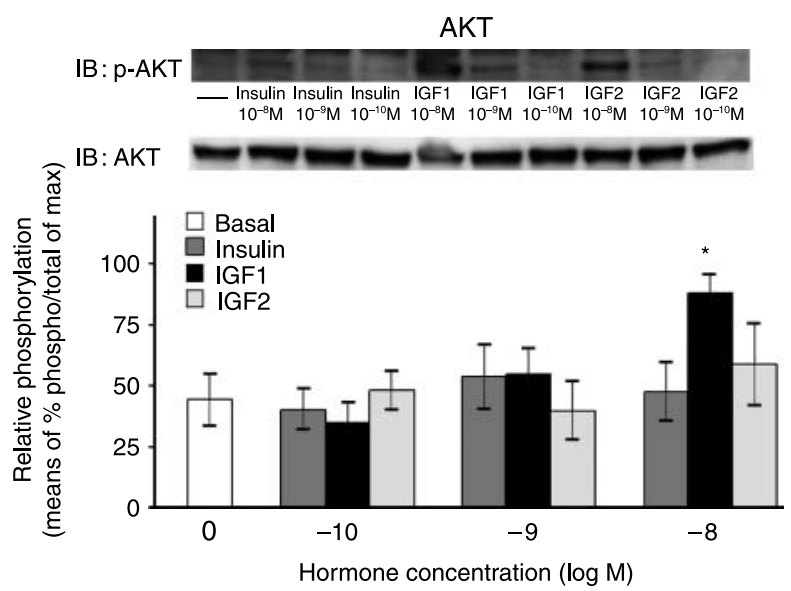

Figure 6 Activation of AKT (PKB). HASMC were exposed for $10 \mathrm{~min}$ to insulin, IGF1, and IGF2 at concentrations $10^{-10}$ $10^{-8} \mathrm{~mol} / \mathrm{l}$. AKT phosphorylation was analyzed using a specific antibody detecting phospho-AKT 1/2/3 phosphorylated at threonine 308. Similar results were obtained in four independent experiments. ${ }^{\star} P<0.05$. 

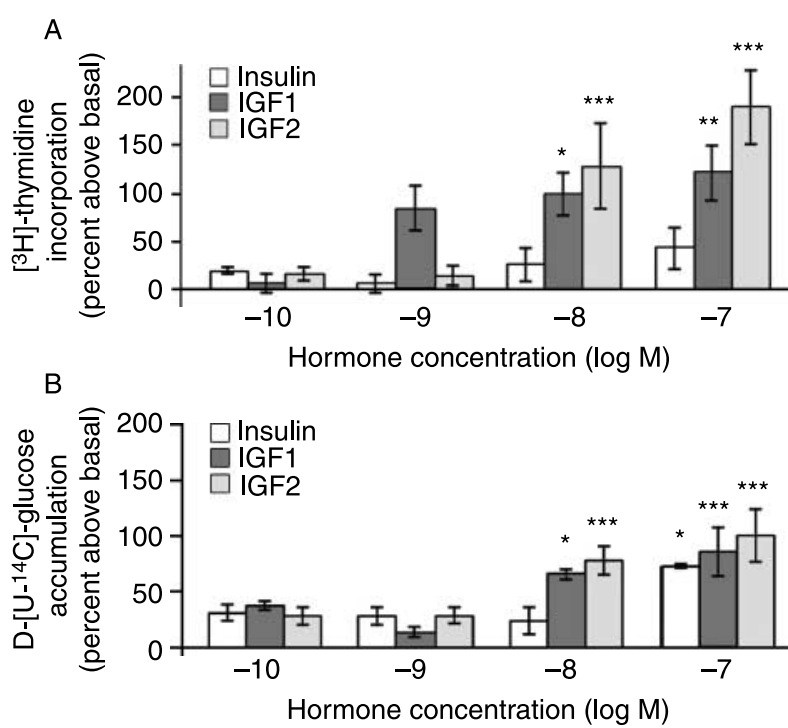

Figure 7 (A) Effect of insulin, IGF1, and IGF2 on $\left[{ }^{3} \mathrm{H}\right]$-thymidine incorporation into DNA in HASMC. Confluent cells, serum starved $24 \mathrm{~h}$ before experiment, were incubated at $37^{\circ} \mathrm{C}$ for $2 \mathrm{~h}$ in serum free medium in the presence of $\left[{ }^{3} \mathrm{H}\right]$-thymidine and polypeptides at concentrations $10^{-10}-10^{-7} \mathrm{~mol} / \mathrm{l}$. Data are expressed as percent thymidine incorporation above basal and are measurements from 10 independent experiments. Bars are mean \pm S.E.M. of 10 experiments. (B) Effect of insulin, IGF1 and IGF2 on $D-\left[U^{14}-C\right]-g l u c o s e$ accumulation in HASMC. Confluent cells, serum starved $24 \mathrm{~h}$ before experiment, were incubated at $37^{\circ} \mathrm{C}$ for $24 \mathrm{~h}$ in serum-free medium in the presence of $\mathrm{D}-\left[\mathrm{U}^{14}-\mathrm{C}\right]$-glucose and polypeptides at the concentrations of $10^{-10}-10^{-7} \mathrm{~mol} / \mathrm{l}$. Data are expressed as percent glucose accumulation above basal and are measurements from 10 independent experiments. Bars are mean \pm S.E.M. of 10 experiments. ${ }^{\star} P<0.05,{ }^{\star \star} P<0.01$, ${ }^{\star \star \star} P<0.001$

tyrosine phosphorylated IGF1R $\beta$-subunits and also co-precipitated IR $\beta$-subunits which are tyrosine phosphorylated. There is little difference in the molecular weight between IR and IGF1R $\beta$-subunits and it was not possible to clearly separate them into two different bands as we succeeded to do in rat aortic smooth muscle cells (Johansson \& Arnqvist 2006). In HASMC the IRs that co-precipitated with the IGF1Rs were not phosphorylated by low concentrations of insulin which showed a lack of insulin effect at $10^{-10}-10^{-9} \mathrm{~mol} / \mathrm{l}$. This is in conformity with the view mentioned above, that hybrid IR/IGF1R have low affinity for insulin (Soos et al. 1993, Siddle et al. 2001).

IGF2 $10^{-8} \mathrm{~mol} / \mathrm{l}$ activated the IGF1R $\beta$-subunit and tended to activate IR in HASMC. This result is in agreement with the observation that the affinity of IGF2 for the IGF1R is about 10-fold lower than IGF1 itself (Jones \& Clemmons 1995). IGF2 at the $10^{-8} \mathrm{~mol} / 1$ also tended to activate the IR. The affinity of IGF2 for IRA is only 10-fold lower than insulin itself, which is why IGF2 is able to activate the IR (Frasca et al. 1999). We found IRA to be the predominant IR isoform expressed in HASMC. However, since we found no significant activation of IR by insulin itself, probably due to incorporation of IR into hybrid IR/IGF1R, as discussed above, the effect of IGF2 on IR was probably due to activation of IR/IGF1R hybrid receptors. A free IGF2 concentration of $10^{-8} \mathrm{~mol} / 1$ can probably be obtained in vivo (Frystyk et al. 1994) and our results therefore suggest that IGF2 may be of importance for human VSMC function (Fig. 7).

Receptor tyrosine kinases of the insulin-like growth factor family promote growth and mediate metabolic signals (Kim \& Accili 2002). The IR and IGF1R activated receptor tyrosine kinases phosphorylate IRS proteins linked to the activation of the two main signaling pathways. The phosphatidylinositol 3-kinase pathway (PI3K)-AKT/protein kinase pathway is responsible for most of the metabolic actions, while the Ras-mitogenactivated protein kinase pathway regulates expression of some genes and cooperates with the PI3K pathway to control cell growth and differentiation (Taniguchi $e t a l$. 2006). In this study we found that the activation of IGF1R was followed by activation of IRS1, AKT, and ERK $1 / 2$ and also by biological effects. We previously showed the activation of IR by insulin $10^{-10}-10^{-9} \mathrm{~mol} /$ 1 in coronary artery smooth muscle cells indicating that IR can be activated by insulin in human VSMCs (Chisalita \& Arnqvist 2005) but this was not accompanied by biological effects. In the current study, there was no activation of the IR by physiological concentrations of insulin in HASMC as mentioned above and insulin $10^{-10}-10^{-9} \mathrm{~mol} / \mathrm{l}$ did not activate IRS1,

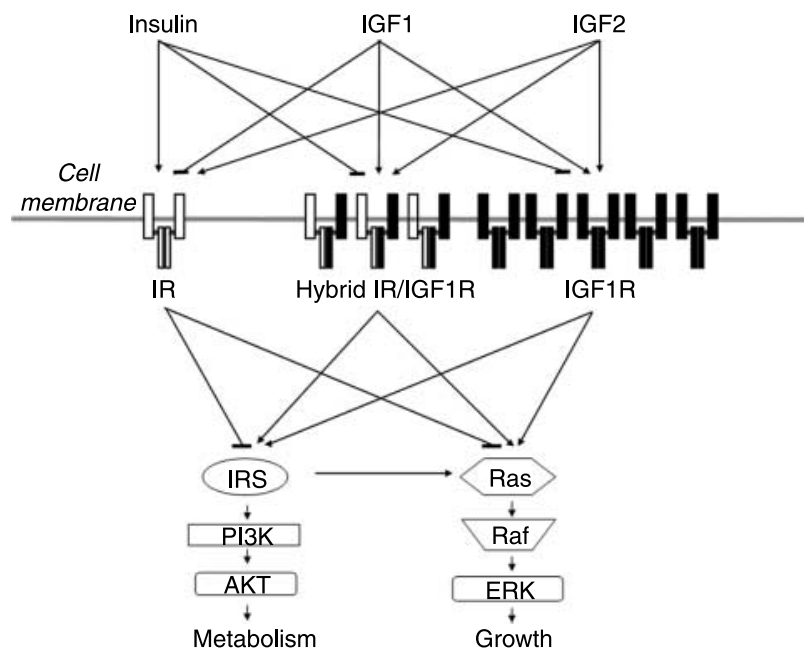

Figure 8 Proposed model for insulin resistance in HASMC. The insulin resistance of vascular smooth muscle is located at the receptor level. Due to the low number of IRs there are not enough receptors activated by insulin to generate a downstream signal. However, the IR $\beta$-subunit is activated by IGF1 when incorporated into hybrid IR/IGF1R. Both IGF1 and IGF2 activate the IGF1R and the hybrid IR/IGF1R and this elicits downstream signaling and biological effects. 
ERK $1 / 2$, or AKT and had no biological effects on glucose accumulation or DNA-synthesis. This suggests that the available insulin holoreceptors in the aortic VSMCs are too few to generate a signal that is propagated. The insulin resistance of vascular smooth muscle therefore seems to be located at the receptor level as we recently described in human microvascular endothelial cells (Johansson et al. 2008). In accordance with our proposed mechanism for insulin resistance in human VSMCs (Fig. 8), disruption of IGF1R in breast cancer cells, osteoblast, and rat VSMC is followed by an increased fraction of insulin holoreceptors and reduced insulin resistance (Fulzele et al. 2007, Zhang et al. 2007, Engberding et al. 2009).

Insulin was found to stimulate glucose accumulation in HASMC at a concentration of $10^{-7} \mathrm{~mol} / \mathrm{l}$, but not at lower concentrations. At such a high concentration that is far above what can be reached in vivo (Olsson et al. 1988) insulin is known to cross react with IGF1 receptors (Banskota et al. 1989, Avena et al. 1999) and the effect of insulin on glucose accumulation is probably elicited by an activation of IGF1R or hybrid IR/IGF1R. It is therefore crucial to use physiological concentrations $\left(\leq 10^{-9} \mathrm{~mol} / \mathrm{l}\right)$ of insulin and IGF1 in studies in vitro to be able to extrapolate the results to in vivo conditions.

Our results clearly demonstrate that HASMC are sensitive to IGF1 and IGF2, but insulin resistant at the receptor level due to the low fraction of available IRs and impairment in downstream signaling pathway (Fig. 8). Furthermore, here, we show that IGF1R are considerably more abundant than IR, and reveal the presence of hybrid IR/IGF1R that probably modulates the insulin resistance of HASMC.

\section{Declaration of interest}

The authors declare that there is no duality of interest associated with this manuscript.

\section{Funding}

Financial support was obtained from the County of Östergötland and Barndiabetesfonden.

\section{Acknowledgements}

We are grateful to Anna-Kristina Granath for excellent technical assistance.

\section{References}

Arnqvist HJ 1974 Action of insulin on vascular and intestinal smooth muscle. Effects on amino acid transport, protein synthesis and accumulation of glucose carbon. Acta Physiologica Scandinavica 90 $132-142$.
Arnqvist HJ 2008 The role of IGF-system in vascular insulin resistance. Hormone and Metabolic Research 40 588-592.

Arnqvist HJ, Berglind R, Dahlkvist HH \& Varenhorst E 1979 Insensitivity to insulin of human arterial tissue in vitro. Acta Physiologica Scandinavica 106 493-494.

Avena R, Mitchell ME, Carmody B, Arora S, Neville RF \& Sidaway AN 1999 Insulin-like growth factor-1 receptors mediate infragenicular vascular smooth muscle cell proliferation in response to glucose and insulin not by insulin receptors. American Journal of Surgery 178 156-161.

Bailyes EM, Nave BT, Soos MA, Orr SR, Hayward AC \& Siddle K 1997 Insulin receptor/IGF-I receptor hybrids are widely distributed in mammalian tissues: quantification of individual receptor species by selective immunoprecipitation and immunoblotting. Biochemical Journal 327 209-215.

Banskota NK, Taub R, Zellner K, Olsen P \& King GL 1989 Characterization of induction of protooncogene c-myc and cellular growth in human vascular smooth muscle cells by insulin and IGF-I. Diabetes 38 123-129.

Chisalita SI \& Arnqvist HJ 2005 Expression and function of receptors for insulin-like growth factor-I and insulin in human coronary artery smooth muscle cells. Diabetologia 48 2155-2161.

Conti E, Andreotti F, Sciahbasi A, Riccardi P, Marra G, Menini E, Ghirlanda G \& Maseri A 2001 Markedly reduced insulin-like growth factor-1 in the acute phase of myocardial infarction. Journal of the American College of Cardiology 38 26-32.

Conti E, Andreotti F, Sestito A, Riccardi P, Menini E, Crea F, Maseri A \& Lanza GA 2002 Reduced levels of insulin-like growth factor-1 in patients with angina pectoris, positive exercise stress test, and angiographically normal epicardial coronary arteries. American Journal of Cardiology 89 973-975.

De Meyts P 1994 The structural basis of insulin and insulin-like growth factor-I receptor binding and negative co-operativity, and its relevance to mitogenic versus metabolic signalling. Diabetologia 37 S135-S148.

De Meyts P 2008 The insulin receptor: a prototype for dimeric, allosteric membrane receptors? Trends in Biochemical Sciences 33 376-384.

Denley A, Bonython ER, Booker GW, Cosgrove LJ, Forbes BE, Ward CW \& Wallace JC 2004 Structural determinants for high-affinity binding of insulin-like growth factor II to insulin receptor (IR)-A, the exon 11 minus isoform of the IR. Molecular Endocrinology 18 2502-2512.

Doran AC, Meller N \& McNamara CA 2008 Role of smooth muscle cells in the initiation and early progression of atherosclerosis. Arteriosclerosis, Thrombosis, and Vascular Biology 28 812-819.

Dupont J \& LeRoith D 2001 Insulin and insulin-like growth factor I receptors: similarities and differences in signal transduction. Hormone Research 55 22-26.

Engberding N, San Martin A, Martin-Garrido A, Koga M, Pounkova L, Lyons E, Lassegue B \& Griendling KK 2009 Insulin-like growth factor-1 receptor expression masks the antiinflammatory and glucose uptake capacity of insulin in vascular smooth muscle cells. Arteriosclerosis, Thrombosis, and Vascular Biology 29 408-415.

Federici M, Porzio O, Zucaro L, Fusco A, Borboni P, Lauro D \& Sesti G 1997 Distribution of insulin/insulin-like growth factor-I hybrid receptors in human tissues. Molecular and Cellular Endocrinology 129 121-126.

Frasca F, Pandini G, Scalia P, Sciacca L, Mineo R, Costantino A, Goldfine ID, Belfiore A \& Vigneri R 1999 Insulin receptor isoform A, a newly recognized, high-affinity insulin-like growth factor II receptor in fetal and cancer cells. Molecular and Cellular Biology 19 3278-3288.

Frattali AL \& Pessin JE 1993 Relationship between alpha subunit ligand occupancy and beta subunit autophosphorylation in insulin/insulin-like growth factor-1 hybrid receptors. Journal of Biological Chemistry 268 7393-7400. 
Frystyk J, Skjaerbaek C, Dinesen B \& Orskov H 1994 Free insulin-like growth factors (IGF-I and IGF-II) in human serum. FEBS Letters 348 $185-191$.

Fulzele K, DiGirolamo DJ, Liu Z, Xu J, Messina JL \& Clemens TL 2007 Disruption of the insulin-like growth factor type 1 receptor in osteoblasts enhances insulin signaling and action. Journal of Biological Chemistry 282 25649-25658.

Johansson GS \& Arnqvist HJ 2006 Insulin and IGF-I action on insulin receptors, IGF-I receptors, and hybrid insulin/IGF-I receptors in vascular smooth muscle cells. American Journal of Physiology. Endocrinology and Metabolism 291 E1124-E1130.

Johansson GS, Chisalita SI \& Arnqvist HJ 2008 Human microvascular endothelial cells are sensitive to IGF-I but resistant to insulin at the receptor level. Molecular and Cellular Endocrinology 296 58-63.

Jones JI \& Clemmons DR 1995 Insulin-like growth factors and their binding proteins: biological actions. Endocrine Reviews 16 3-34.

Juul A, Scheike T, Davidsen M, Gyllenborg J \& Jorgensen T 2002 Low serum insulin-like growth factor I is associated with increased risk of ischemic heart disease: a population-based case-control study. Circulation 106 939-944.

Kim JJ \& Accili D 2002 Signalling through IGF-I and insulin receptors: where is the specificity? Growth Hormone and IGF Research 12 84-90.

King GL, Buzney SM, Kahn CR, Hetu N, Buchwald S, Macdonald SG \& Rand LI 1983 Differential responsiveness to insulin of endothelial and support cells from micro- and macrovessels. Journal of Clinical Investigation 71 974-979.

King GL, Goodman AD, Buzney S, Moses A \& Kahn CR 1985 Receptors and growth-promoting effects of insulin and insulin like growth factors on cells from bovine retinal capillaries and aorta. Journal of Clinical Investigation 75 1028-1036.

Lakka HM, Laaksonen DE, Lakka TA, Niskanen LK, Kumpusalo E, Tuomilehto J \& Salonen JT 2002 The metabolic syndrome and total and cardiovascular disease mortality in middle-aged men. Journal of the American Medical Association 288 2709-2716.

Mosthaf L, Grako K, Dull TJ, Coussens L, Ullrich A \& McClain DA 1990 Functionally distinct insulin receptors generated by tissue-specific alternative splicing. EMBO Journal 9 2409-2413.

Moxham CP, Duronio V \& Jacobs S 1989 Insulin-like growth factor I receptor beta-subunit heterogeneity. Evidence for hybrid tetramers composed of insulin-like growth factor I and insulin receptor heterodimers. Journal of Biological Chemistry 264 13238-13244.

Nathan DM, Cleary PA, Backlund JY, Genuth SM, Lachin JM, Orchard TJ, Raskin P \& Zinman B 2005 Intensive diabetes treatment and cardiovascular disease in patients with type 1 diabetes. New England Journal of Medicine 353 2643-2653.

Olsson PO, Arnqvist HJ \& Von Schenck HV 1988 Free insulin profiles during intensive treatment with biosynthetic human insulin. Diabetes and Metabolism 14 253-258.

Pandini G, Vigneri R, Costantino A, Frasca F, Ippolito A, Fujita-Yamaguchi Y, Siddle K, Goldfine ID \& Belfiore A 1999 Insulin and insulin-like growth factor-I (IGF-I) receptor overexpression in breast cancers leads to insulin/IGF-I hybrid receptor overexpression: evidence for a second mechanism of IGF-I signaling. Clinical Cancer Research 5 1935-1944.
Pandini G, Frasca F, Mineo R, Sciacca L, Vigneri R \& Belfiore A 2002 Insulin/insulin-like growth factor I hybrid receptors have different biological characteristics depending on the insulin receptor isoform involved. Journal of Biological Chemistry 277 39684-39695.

Rinderknecht E \& Humbel RE 1978a Primary structure of human insulin-like growth factor II. FEBS Letters 89 283-286.

Rinderknecht E \& Humbel RE $1978 b$ The amino acid sequence of human insulin-like growth factor I and its structural homology with proinsulin. Journal of Biological Chemistry 253 2769-2776.

Sakai K \& Clemmons DR 2003 Glucosamine induces resistance to insulin-like growth factor I (IGF-I) and insulin in Hep G2 cell cultures: biological significance of IGF-I/insulin hybrid receptors. Endocrinology 144 2388-2395.

Saltiel AR \& Kahn CR 2001 Insulin signalling and the regulation of glucose and lipid metabolism. Nature 414 799-806.

Siddle K, Urso B, Niesler CA, Cope DL, Molina L, Surinya KH \& Soos MA 2001 Specificity in ligand binding and intracellular signalling by insulin and insulin-like growth factor receptors. Biochemical Society Transactions 29 513-525.

Soos MA \& Siddle K 1989 Immunological relationships between receptors for insulin and insulin-like growth factor I. Evidence for structural heterogeneity of insulin-like growth factor I receptors involving hybrids with insulin receptors. Biochemical Journal 263 553-563.

Soos MA, Field CE \& Siddle K 1993 Purified hybrid insulin/insulin-like growth factor-I receptors bind insulin-like growth factor-I, but not insulin, with high affinity. Biochemical Journal 290 419-426.

Taniguchi CM, Emanuelli B \& Kahn CR 2006 Critical nodes in signalling pathways: insights into insulin action. Nature Reviews. Molecular Cell Biology 7 85-96.

Ullrich A, Gray A, Tam AW, Yang-Feng T, Tsubokawa M, Collins C, Henzel W, Le Bon T, Kathuria S, Chen E et al. 1986 Insulin-like growth factor I receptor primary structure: comparison with insulin receptor suggests structural determinants that define functional specificity. EMBO Journal 5 2503-2512.

Ward CW, Lawrence MC, Streltsov VA, Adams TE \& McKern NM 2007 The insulin and EGF receptor structures: new insights into ligandinduced receptor activation. Trends in Biochemical Sciences $\mathbf{3 2}$ 129-137.

Yamaguchi Y, Flier JS, Yokota A, Benecke H, Backer JM \& Moller DE 1991 Functional properties of two naturally occurring isoforms of the human insulin receptor in Chinese hamster ovary cells. Endocrinology 129 2058-2066.

Zhang H, Pelzer AM, Kiang DT \& Yee D 2007 Down-regulation of type I insulin-like growth factor receptor increases sensitivity of breast cancer cells to insulin. Cancer Research 67 391-397.

Received in final form 28 May 2009

Accepted 8 July 2009

Made available online as an Accepted Preprint 8 July 2009 